\title{
Exploring the impact of CSI effect and Appropriate Media Handling during Crime Investigation
}

\author{
Bhoopesh Kumar Sharma \\ Department of Forensic Science, Amity University Dubai, UAE \\ Mayssa Hachem \\ Department of Forensic Science, Amity University Dubai, UAE \\ Raeesa Bashir \\ School of Management, Amity University Dubai, UAE \\ Ved P. Mishra \\ Department of Engineering, Amity University Dubai, UAE
}

\begin{abstract}
In the last few years, media has raised the number of shows based on crime scene investigation on televisions. Due to a drastic increase in the audience, many people assume that they have a full understanding and knowledge base of crime scene investigation. The effect of such shows on the general audience, as well as on the jurisdiction, is considered as the CSI Effect. The consequences of the CSI Effect have impacted the public as well as law enforcement. Media can also be regarded as an investigative tool in crime investigation in the forensic field. The present review focuses on investigating the impact of the CSI effect and addressing fundamental issues through effective media handling in crime and criminal investigations. The development of suitable media strategies, mechanisms for managing media, disclosure, and acquisition of information are also discussed. The proposed strategies will support the general public and law enforcement community to use media handling in major crimes and to approach the proper, unbiased, impartial, and timely forensic investigations.
\end{abstract}

Keywords: Media, Media Handling, Crime Investigations, CSI effect, Law Enforcement, Forensic Science.

\section{Introduction}

Media has a great influence on shaping public opinion about significant political and social issues (Happer \& Philo, 2013). Whether it is television, press, radio, internet, or any other form of social media, it affects the public in general, the politicians, and law enforcement as well. The effect of such crime shows on the general audience, and the jurisdiction is popularly known as the "CSI Effect" (Podlas, 2006). The Maricopa County survey found that due to the CSI effect, a majority of prosecutors were changing their litigation strategies in response (Thomas, 2006). Later, researchers have proposed that the police investigator or forensic team, and the media team must work together for a successful crime investigation (Palmiotto \& Kingshott, 2010). Appropriate media management provides the investigator with direct passage to the public to seek witnesses and provides realistic updates without compromising the complete investigative process (Chermak et al., 2006). In fact, in any criminal investigation, media handling has been recognized as a crucial skill of the investigating officer. It is an essential means for captivating valuable information from the general public, although media dealing can take up precious time and resources during the acute stages of an investigation. As a routine, many law enforcement officials in different countries inform the general public of their activities, about new rules and regulations, new and amended laws and often use the media to present this information to communicate the aspects of a particular incident or an issue relating to the incident in question (Barak, 2007). The role of media in informing the public of all matters of interest is always a point of debate that identifies the need for a collaborative approach and practice of MediaPolice Relations (Mawby, 2002). Dubois, 2002 showed that $95 \%$ of the population rely on media for crime and police Information.

The present review explores the CSI effect on the public, law enforcement, and the media interest in crime investigation. In various criminal investigations, the fundamental issues of effective media control and handling, as well as the disclosure and media acquisition 
of information, are discussed. These approaches will be useful in further forensic investigations.

\section{BACKGROUND}

\section{The CSI effect on law enforcement \& public}

In this section, the impact of CSI TV show on law enforcement and the public community is assessed. First, concerning the law enforcement, it has often been criticized that the television shows including Crime Scene Investigation 'CSI', 'Medical Detectives', etc. have fostered in judges' unreasonable anticipations about forensic evidence. Judges require absolute forensic evidence of guilt; job much harder ("The CSI Effect-Crime Museum," 2019).

Considering the CSI effect on the public, it may influence the criminals to apply new modus operandi (M.O). So, the criminals can escape themselves out from any conviction.

Besides, many scholars and educators consider CSI as a recruitment tool for students in the area of forensic science. Most of the students enroll the forensic science studies because of an interest inspired by watching CSI (Mardis, 2006). Also, this has been observed in a survey done at Amity University Dubai during admission open houses and admission data. The students have mentioned their interest in

\begin{tabular}{|l|l|l|l|}
\hline $\begin{array}{l}\text { ACADEMIC YEARS OF } \\
\text { ADMISSIONS IN } \\
\text { FORENSIC SCIENCE AT } \\
\text { AMITY UNIVERSITY DUBAI }\end{array}$ & $\begin{array}{l}\text { TOTAL NUMBER OF } \\
\text { STUDENTS ADMITTED IN } \\
\text { FOAENSIC SCIENCE AT } \\
\text { AMITY UNIVERSITY DUBAI }\end{array}$ & $\begin{array}{l}\text { STUDENTS SHOWN } \\
\text { INTEREST IN THE } \\
\text { PROGRAM DUE TO CSI OR } \\
\text { OTHER SHOWS EFFECT }\end{array}$ & $\begin{array}{l}\text { PEACENTOGE OF OTHER SUCH TV } \\
\text { SHOWS }\end{array}$ \\
\hline 2014 & 42 & 26 & 62 \\
\hline 2015 & 26 & 22 & 84 \\
\hline 2016 & 24 & 21 & 85 \\
\hline 2017 & 26 & 23 & 88 \\
\hline 2018 & 33 & 31 & 93 \\
\hline
\end{tabular}

Figure 1: Shows the data of admissions at Amity University Dubai from year 2014-2018 in Forensic Science

otherwise, they will acquit wrongly. The Maricopa County survey found that due to the CSI effect, a majority of prosecutors were changing their litigation strategies in response (Thomas, 2006). Several surveys have reliably shown that many court members believe that a CSI effect exists (Cole \& Dioso-Villa, 2011; Mancini, 2011; Smith et al., 2011). In 'The Media and the CSI Effect' book published in 2011, the author observed the CSI effect on more than 400 prosecutors and concluded that 'The CSI effect promotes unlawful intrusion of the criminal justice system into the American population's difficult private lives and promotes unjust convictions' (Stevens, 2011). Also, in a recent case named case of Leigh Stubbs, published in Crime Museum library, a Mississippi woman was sentenced on questionable forensic testimony to 44 years in prison and was convicted of physically assaulting her friend even though there was no physical evidence. Later on, in a sting operation, it was found that the forensic expert was knowingly giving false information, and yet the prosecution to this day still defends his cases. In such cases, the influence of CSI can be seen easily, making the actual professional's the area of forensic science after getting fascinated by various crime series like CSI etc. Figure 1 and 2 below demonstrate the results of the survey done at Amity University Dubai that clearly shows the impact of crime TV series on students admissions in Forensic Sciences. Hence, it can be understood by this study that such shows also served as the applicant pool of a program, which should improve the quality of individuals entering police forensics in the long term.

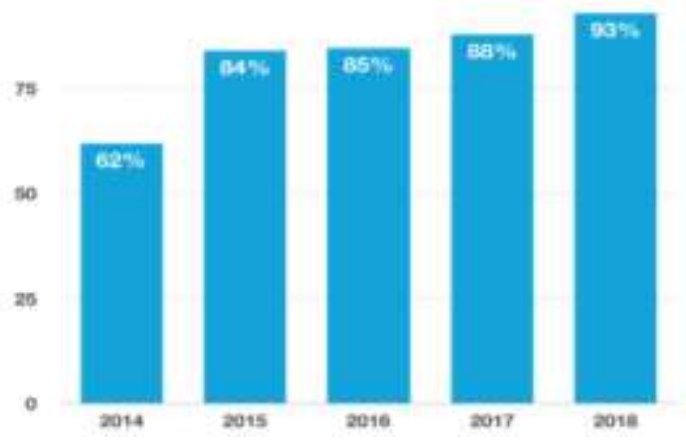

Figure 2: Graph showing the impact on admissions in forensic science at Amity University due to CSI effect and other such TV Shows 


\section{Media as an investigative tool in crime}

Media has been considered as an essential tool in crime scene investigation for investigators and law enforcement. Investigators utilize the support from media in several criminal investigations to achieve numerous objectives such as the identification of the victim, identification of the suspects, identification of the vehicle involved in crime, establish victim's or offender's last movement and so on.

In many recent cases like disappearance of MH370 (Malaysian airlines flight 370) on March 8, 2014, media has played a significant role not only in informing the society about the updates but also helped the investigators throughout in search of the missing flight. In one of the recent articles (Llewelyn A, 2019) the author during a survey said that 'residents of Kuda Huvadhoo in the Maldives reported seeing and hearing a "low-flying jumbo jet like structure" above their houses in the morning of March 8 (Maldivian Daily Haveeru). There have been several theories postulated by forensic experts, investigators, and researchers all over the world, and the media has played a vital role in connecting these investigators in the investigation. In the other case of suspicious crash of Ethiopian Airlines (Boeing 737 Max) media till date is following the investigation and supporting not only in updating the information to the public but also assisting in the investigation and formulation of new regulatory rules for boeing 737 air crafts ("Boeing completes 737 Max software upgrade", 2019). The world is well aware of the famous 26/11 Mumbai terror attack at Taj Mahal Hotel in India on November 26' 2008. The active role media played to cover that is legendary. On the one hand, media was showing the live telecast to the world, and on the other side, the military officials were taking the lead from the press to complete the operation ("10 Years of 26/11: Unforgettable Images of Mumbai Terror Attack", 2019).

Investigators can further use different approaches of media, including press media or social media, considered as appropriate investigative tools. For example, shortly after encountering an offense, media can be used to reach a large population across a wide geographic area. Even local and regional media can reach a considerable audience and can address specific target audiences more significantly (Munster, 1992). Besides, through social media, investigators can discover a lot of valuable information just by searching a subject's profile. It opens up a window into a person's life that would not necessarily be seen otherwise. Frequently, offenders' post shreds of evidence of their crimes on social media, and this can help the investigators to achieve their goal. Most investigators estimated that during the first two-three days of an inquiry, they spent their crucial time dealing with the media (Mawby, 2002; Mawby, 1997). Although investigators can decide the contents and timings of a press release, however, they are not always in a position to determine how the media will portray this information. This can be well achieved by improving media-police relations and also by providing investigating officers sufficient training and ability in media handling.

Media professionals are always interested in severe crimes investigations such as rape and murder and demand the appropriate results to the public, particularly in the very first few days of an inquest (Adhami \& Browne, 1996). Several factors govern the level of press interest in the coverage of the investigation. Most commonly, the age, social status, background history of the victim, and also location of the offense was most widely perceived as having an impact on media coverage level. The media usually attempts to deliver to the wants of consumers to watch news that is interesting and also provides something that will keep drawing their attention (Xiang \& Sarvary, 2007). Where media interest is very high, one of the significant issues from media handling in such investigations is the demands of resources on the investigative team.

In some cases, attorneys have created websites that allow clients to see all necessary information about a case in which the lawyers are involved (Groark, 2010). Many members of the Society of Professional Journalists believe that the precursor of justice and the foundation of democracy is public clarification. The journalist must pursue these aims through the search for truth and a clear and comprehensive account of all events and issues ("SPJ Code of Ethics - Society of Professional Journalists," 2019). In addition to investigators, Law enforcement can also use social media to acquire probable cause for a search warrant. 


\section{Addressing Media Strategy}

Media handling is a significant issue for investigators and law enforcement during the investigation process from the initial finding of a crime to the trial and, in some cases, to the appeal process. Furthermore, media handling showed to affect police services, including active investigations, minimizing crime fears, and ensuring a safe and equitable society (Mawby et al., 1997). Hence, media strategies should be dynamic, flexible, and bespoke to specific investigations through the application of a narrow approach (Kellner, 2011). As discussed below, several goals in the media strategies should be addressed in criminal investigations:

- Best use of media to acquire information required by the investigating officer

- Effective administration and management of media interest to minimize potential interference with crime scenes, witnesses, victims and suspects

- Providing accurate information to the public along with police response

- Reduce avoidable community concern about crime fear

- Publication of appropriate advice on crime prevention

- Demonstration of police service's professionalism.

By considering the appropriate timing, decisive selection, and presentation of information to be disclosed, the Investigating Officer or law enforcement can effectively achieve these goals.

\section{Dissemination and Media Acquisition of Information}

The media and the Police services worldwide provide accurate information about any crime to the public (The Public and Broadcasting, 2019). The fact that should be considered during the disclosure of crimes' information is, what should not be disclosed, rather than what should be disclosed to the media. Researchers have established a relationship between the disclosure of information through media and the behavior of offenders. For example, advertising of the offender's strategies for protecting the public can lead offenders to adapt their behavior (Elliott et al., 1995). To avoid such consequences, the investigative team's decision about the disclosure of information should be subjective and based on the unusual circumstances of the offense, the victim, and the inquiry. There should be no disclosure of certain details about an offense and its investigation. There exist various reasons for non-disclosure of specific facts. The investigator must consider that the public should refrain from disclosing individual facts relating to the crime to help identify the offender. In the first place, many investigators will retain certain pieces of evidence to increase the length of interest in

Table 1: The objectives and probable effects of disclosure and non-disclosure of information to media

\begin{tabular}{|c|c|c|}
\hline & Disclosure of Information & Non-disclosure of information \\
\hline Objectives & $\begin{array}{l}\text { 1- Investigation reports available to the } \\
\text { general public anytime } \\
2 \text { - Public can intervene in the } \\
\text { investigation as a support to the police } \\
\text { services } \\
\text { 3- Minimizes newscaster's supposition } \\
\text { 4- Provokes offender response } \\
\text { - Crime prevention advice to the } \\
\text { public }\end{array}$ & $\begin{array}{l}\text { 1- Information to assist with investigative } \\
\text { strategies } \\
\text { 2- Reduce anxiety and fear of crime among } \\
\text { community } \\
\text { 3- Minimize suffering to victim's family } \\
\text { 4- Prevent offenders from destroying } \\
\text { evidence } \\
\text { 5- Avoid changing offender behaviors in } \\
\text { additional offenses and it is easy to capture }\end{array}$ \\
\hline $\begin{array}{l}\text { Probable } \\
\text { effects }\end{array}$ & $\begin{array}{l}\text { 1-The information cannot be used } \\
\text { further in interviews with suspects, } \\
\text { victims and witnesses. } \\
\text { 2- Less information available later on } \\
\text { for disclosure } \\
\text { 3- Possibility of repeating the modus } \\
\text { operandi by further criminals and also } \\
\text { destruction of forensic evidences }\end{array}$ & $\begin{array}{l}\text { 1-May hinder the public response } \\
\text { 2-Increased risk of press investigations that } \\
\text { may consequently damage the overall } \\
\text { investigation } \\
\text { 3- Increased risk of misinformation and } \\
\text { speculation }\end{array}$ \\
\hline
\end{tabular}


the press through the decision to hold back details of an offense permanently is usually based on evidence (Elliott et al., 1995). The objectives and probable effects of disclosure and non-disclosure of information to media are described in table 1.

\section{Materials and Methods}

Considering the above-mentioned effect of crime TV shows and appropriate media handling strategy for the dissemination of information following objectives were taken for the study:

1. To study the effect of crime TV shows on the mentality of criminals, judiciary system and population, in general, to observe whether or not crime TV and news creates fear of crime in public.

2. To study the role of the media as a useful investigative tool and efficient media handling and its strategy.

3. Proclamation of holding back / disclosing information regarding the crime.

The statistical analysis intends to examine the impact of the CSI effect and appropriate media handling during a crime investigation. A pilot survey of 100 samples based on simple random sampling (SRS) was conducted at Amity University Dubai.
Since we had more than two proportions to examine, therefore Chi-square test was used. Chi-square tests enabled us to test whether more than two population proportions can be considered equal. The observed frequencies, f0, are the actual values obtained, which are recorded on the original contingency table. The expected frequencies, fe, are those which are theoretically expected by considering the overall proportions of each classification (as shown in table 2).

Under the hypothesis of independent of attributes, the value of chi-square with (r1)(c-1) degrees of freedom (Dof) can be computed as

$$
\chi^{2}=\sum \frac{\left(f_{0}-f_{e}\right)^{2}}{f_{e}}
$$

Null Hypothesis H0: That the two attributes under consideration are independent i.e, the local opinion of different age-group is independent of the impact of crime scene investigation and efficacious media handling.

Alternate Hypothesis H1: That the two attributes under consideration are dependent i.e, the local opinion of different age-group is dependent on the impact of crime scene investigation and efficacious media handling.

Table 2: Shows the statistical analysis on the basis of the samples collected in two different age groups to observe the response of the public in general.

\begin{tabular}{|c|c|c|c|c|c|c|}
\hline \multirow{2}{*}{\multicolumn{7}{|c|}{$\begin{array}{l}\text { Response Table to Observe the Impact of CSI and Media in Crime I } \\
\text { Q1. How many days a week do you watch television crime shows? }\end{array}$}} \\
\hline & & & & & & \\
\hline 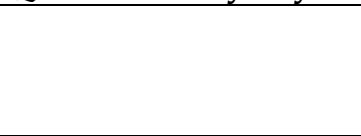 & $\begin{array}{c}\text { Age group } \\
\text { I (18-30 } \\
\text { years) }\end{array}$ & $\begin{array}{l}\text { Age group } \\
\text { II (31-45 } \\
\text { years) }\end{array}$ & Total & $\chi^{2}$ & P-value & $\begin{array}{l}\text { Remarks } \\
{ }^{*} N S=\text { Non-significant } \\
{ }^{*} S=\text { Significant }\end{array}$ \\
\hline Never & 14 & 13 & 27 & \multirow{5}{*}{$\begin{array}{l}3.37 \\
\text { Dof }=3\end{array}$} & \multirow[t]{5}{*}{0.338} & \multirow[t]{5}{*}{ NS } \\
\hline Less than once a week & 20 & 28 & 48 & & & \\
\hline 2-3times a week & 13 & 7 & 20 & & & \\
\hline 4-7times a week & 3 & 2 & 5 & & & \\
\hline Total & 50 & 50 & 100 & & & \\
\hline \multicolumn{7}{|c|}{ Q2. Do you agree these crime tv shows affects the society? } \\
\hline Strongly Agree & 21 & 13 & 34 & \multirow{4}{*}{$\begin{array}{l}8.15 \\
\text { Dof }=3\end{array}$} & \multirow[t]{5}{*}{0.043} & \multirow[t]{5}{*}{ S } \\
\hline Agree & 18 & 22 & 39 & & & \\
\hline Neutral & 6 & 14 & 21 & & & \\
\hline Disagree & 5 & 1 & 6 & & & \\
\hline Total & 50 & 50 & 100 & & & \\
\hline \multicolumn{7}{|c|}{ Q3. Do you agree these crime TV shows affect the mentality of criminals? } \\
\hline Strongly Agree & 23 & 9 & 32 & \multirow{5}{*}{ Dof $=3$} & \multirow[t]{5}{*}{0.0258} & \multirow[t]{5}{*}{$S$} \\
\hline Agree & 14 & 23 & 37 & & & \\
\hline Neutral & 7 & 11 & 18 & & & \\
\hline Disagree & 6 & 7 & 13 & & & \\
\hline Total & 50 & 50 & 100 & & & \\
\hline
\end{tabular}




\begin{tabular}{|c|c|c|c|c|c|c|}
\hline \multicolumn{7}{|c|}{ Q4. Do you agree these crime TV shows affect the judiciary system in a positive way? } \\
\hline Strongly Agree & 7 & 3 & 10 & \multirow{6}{*}{$\begin{array}{l}5.27 \\
\text { Dof }=4\end{array}$} & \multirow[t]{6}{*}{0.2607} & \multirow[t]{6}{*}{ NS } \\
\hline Agree & 9 & 15 & 24 & & & \\
\hline Neutral & 18 & 21 & 39 & & & \\
\hline Disagree & 13 & 7 & 20 & & & \\
\hline Strongly Disagree & 3 & 4 & 7 & & & \\
\hline Total & 50 & 50 & 100 & & & \\
\hline \multicolumn{7}{|c|}{ Q5. Do you agree that crime TV shows creates fear of crime in population? } \\
\hline Agree & 24 & 22 & 46 & \multirow{4}{*}{$\begin{array}{l}0.76 \\
\text { Dof }=2\end{array}$} & \multirow[t]{4}{*}{0.6839} & \multirow[t]{4}{*}{ NS } \\
\hline Neutral & 17 & 21 & 38 & & & \\
\hline Disagree & 9 & 7 & 16 & & & \\
\hline Total & 50 & 50 & 100 & & & \\
\hline \multicolumn{7}{|c|}{ Q6. Do you agree that news about crime creates fear of crime in population? } \\
\hline Strongly Agree & 4 & 6 & 10 & \multirow{6}{*}{$\begin{array}{l}2.87 \\
\text { Dof }=4\end{array}$} & \multirow[t]{6}{*}{0.5798} & \multirow[t]{6}{*}{ NS } \\
\hline Agree & 23 & 15 & 38 & & & \\
\hline Neutral & 16 & 19 & 35 & & & \\
\hline Disagree & 5 & 7 & 12 & & & \\
\hline Strongly Disagree & 2 & 3 & 5 & & & \\
\hline Total & 50 & 50 & 100 & & & \\
\hline \multicolumn{7}{|c|}{ Q7. Do you agree that media can be used an effective investigative tool? } \\
\hline Strongly Agree & 22 & 9 & 31 & \multirow{5}{*}{$\begin{array}{l}8.14 \\
\text { Dof }=3\end{array}$} & \multirow[t]{5}{*}{0.0432} & \multirow[t]{5}{*}{ S } \\
\hline Agree & 14 & 18 & 32 & & & \\
\hline Neutral & 8 & 13 & 21 & & & \\
\hline Disagree & 6 & 10 & 16 & & & \\
\hline Total & 50 & 50 & 100 & & & \\
\hline \multicolumn{7}{|c|}{$\begin{array}{l}\text { Q8. Do you agree that media DO NOT portrays correct information to the general public in all crime } \\
\text { news? }\end{array}$} \\
\hline Strongly Agree & 15 & 6 & 21 & \multirow[t]{3}{*}{8.78} & \multirow[t]{5}{*}{0.0324} & \multirow[t]{5}{*}{ S } \\
\hline Agree & 19 & 18 & 37 & & & \\
\hline Neutral & 10 & 22 & 32 & & & \\
\hline Disagree & 6 & 4 & 10 & \multirow[t]{2}{*}{ Dof $=3$} & & \\
\hline Total & 50 & 50 & 100 & & & \\
\hline \multicolumn{7}{|c|}{$\begin{array}{l}\text { Q9. Do you agree that, if properly managed, media can be a very effective tool in crime } \\
\text { investigation? }\end{array}$} \\
\hline Strongly Agree & 21 & 16 & 37 & \multirow{4}{*}{$\begin{array}{l}1.62 \\
\text { Dof }=2\end{array}$} & \multirow[t]{4}{*}{0.4449} & NS \\
\hline Agree & 17 & 23 & 40 & & & \\
\hline Neutral & 12 & 11 & 23 & & & \\
\hline Total & 50 & 50 & 100 & & & \\
\hline $\begin{array}{l}\text { Q10. Do you agree } \\
\text { to the media? }\end{array}$ & all & mati & ding & ime shor & NOT $b$ & shared by the police \\
\hline Strongly Agree & 6 & 19 & 25 & 10.46 & 0.0334 & \\
\hline Agree & 14 & 12 & 26 & & & $S$ \\
\hline Neutral & 17 & 9 & 26 & & & \\
\hline Disagree & 11 & 7 & 18 & Dof $=4$ & & \\
\hline Strongly Disagree & 2 & 3 & 5 & & & \\
\hline Total & 50 & 50 & 100 & & & \\
\hline
\end{tabular}

\section{Result and Discussion:}

In response to the overall survey, it was seen that in most of the cases we fail to reject our null hypothesis as it was observed that there is no significant difference between the local opinion of different age groups and the impact of crime scene investigation and efficient media handling.

For instance, regarding the effect and impact of crime TV shows, statistics show that both the age group people were found to be interested in watching one or the other crime 
shows and of the opinion that these crime shows have an impact on the society and create fear of crime in general public. The reason may be the heinousness of the crime or the way to showcase it in the media. Also, it was observed that both the age groups agree that the crime tv shows and news affect our judiciary system as well but more in a positive way when appropriately managed. On the other hand, it was seen that there is a significant difference between the local opinion of different age groups and the impact of crime scene investigation and efficient media handling. While analyzing the efficacy of media as an investigative tool, it was observed that young adults between the age group of 18-30 years believe that crime tv shows affect the society and consider the media as a very useful investigative tool involving the use of social media and other available resources. The proper management of media during crime investigation plays a vital role; however, many times media do not portray the correct information as seen in the observation, but it can easily be overcome with the proper management of media in conjunction with the investigating authorities. It was correspondingly perceived in the study that people between the age group of $31-45$ years are of the view that all the information regarding a crime should not be shared by the police to the media to avoid the further fear of crime among society and to facilitate the confidential investigation.

In the present review, we explored the CSI effect on law enforcement and public presenting the way the media can shape the decisions of judges in crime investigation and the influence of CSI on the criminals looking for new modus operandi M.O. The focus was on the vital role of the media as an investigative tool in the investigation of crime, which shows that if managed effectively, the media can make a significant contribution to the inquiry. Later, we discussed the effective way for media handling by proposing different appropriate strategies. A productive and routine relationship should be established between the investigators and the media liaison officer for successful media handling. Although resource limitations do not always allow such effective relationships to occur, However, it is necessary to develop and encourage the willingness of both investigators and media liaison officers to engage in an ongoing dialog (Innes, 1999). After proposing appropriate addressing media strategy, we showed the goals and likely effects of media disclosure and non-disclosure. Indeed, the advantages and disadvantages of disclosure and non-disclosure of the information to the general public and media need to be considered in the development of practical media strategy (Hughes, 2015). How the law enforcement response to the media is also an important factor, along with the timing of communication to optimize coverage and reach the target audience. Specifically, media management requires skills to anticipate public response and legal implications (Innes, 1999). Some of these skills can be developed by considering various factors, including the knowledge about the particular case, the level of media interest, and the messages needed to be given to the public through media appeal. Other factors can be added, such as how the media expected this offense to be interpreted, its subsequent investigation, and the investigative consequences of holding back / disclosing information pieces. Besides all this, the investigation team needs to consider certain good practices that can result in effective media handling ("Media Strategies and Research," 2019). These include skilled media liaison officers who should be formal members within crime investigation teams, at least at the initial stages of the investigation when media interest is at its height. Different practical training sessions for investigating officers should be conducted for designing effective media strategies. The strategies for effective communications between media and investigators/police should be developed. In evaluating the effectiveness of different media, further research work should be undertaken.

\section{IV-Conclusion}

The developed media technology has offered the police and the investigators a great support. Media has been developed over the years and become a primordial factor in our lives. Although various positive effect of media has affected the population and law enforcement worldwide through covering the crime scene investigation. The dissemination of information has also changed since the inception of all police forces and law enforcement agencies with the inclusion of partnership with media. The development of universal communication channels through the internet has provided the facts relating to 
crime statistics, personnel and other social demographics relating to the area being policed that can be easily accessed by law enforcement further and to take necessary action to control the crime in the area or the region. However, to limit the CSI effect, public awareness, and adequate handling of these media coverage should be spread worldwide. This should also include the media literacy campaigns to educate the people and investogators that how media can influence the public opinion. More researches should focus on different approaches dedicated to media handling for effective crime investigation. The improved partnership of the media with the law enforcement community is also a need to enhance investigative procedures.

\section{REFERENCES}

- Adhami, E. \& Browne, D.P. (1996). Major Crime Enquiries: Improving Expert Support for Detectives Special Interest Series Paper No. 9. London: Home Office.

- Barak, G. (2007). Mediatizing Law \& Order: Applying Cottle's architecture of communicative frames to the social construction of crime and justice. Crime Media Culture, 3(1), 101- 109.

- Boeing completes 737 Max software upgrade. (2019). Retrieved from https://www.bbc.co.uk/news/business48276232

- Chermak, S., McGarrell, E., \& Gruenewald, J. (2006). Media coverage of police misconduct and attitudes towards police. An International Journal of Police Strategies and Management, 29(2), 262281.

- Cole, S. A., \& Dioso-Villa, R. (2011). Should judges worry about the CSI Effect? Court Review, 47, 20-31.

- Dubois, J. (2002). 'Media Coverage of Organized Crimes-Police Managers Survey. Trends in Organized Crime, 7(4), 29-54.

- Elliott, M., Browne, K., and Kilcoyne, J. (1995). 'Child sexual abuse prevention: what offenders tell us,' Child Abuse and Neglect 19(5), 579-594.
- Groark, V. (2010). Should a case go webwide? ABA Journal, 96(1), 30-32.

- Happer, C., \& Philo, G. (2013). The role of the media in the construction of public belief and social change. Journal of Social and Political Psychology, 1(1), 321-336.

- Hughes, B. (2015). How Social Media is Changing Police Investigations. Retrieved from https://socialmediaweek.org/blog/2015/ 12 /social-media-changing-policeinvestigations/

- Innes, M. (1999). 'The media as an investigative resource in murder enquiries,' British Journal of Criminology, 39(2), 269-286.

- Kellner, D. (2011). Media culture. London: Routledge, Taylor \& Francis Group.

- $\quad$ Llewelyn, A. (2019). MH370 SHOCK claim: 'Decoy plane used to create illusion the US was responsible'. Retrieved from https://www.express.co.uk/news/weird /1130133/mh370-news-missing-malaysiaairlines-plane-US-maldives-andamancambodia-spt

- Mancini, D. E. (2011). The CSI Effect reconsidered: Is it moderated by the need for cognition? North American Journal of Psychology, 13, 155-174.

- Mardis, M. (2006). It's not just whodunit but how: Science learning and the school library. Knowledge Quest (American Library Association), 35, 12-17.

- Mawby, R.C. (1997). 'Managing Police Media and Public Relations,' in Focus, August 1997. London: Home Office.

- Mawby, R.C. (2002). The policy and practice of the police-media relations. Criminology and Criminal Justice, 2(3), 303-324.

- Mawby, R.I., Ostrihanska, Z \& Wojcik, D. (1997). Police response to crime: The perceptions of victims from two polish cities, Journal Policing and Society, 7(4), 235-252.

- Media Strategies and Research. (2019).

Retrieved from

https://www.mediastrategies.com/ 
- Munster, A. (1992). Media, crime, and criminal justice: Images and realities. Journal Of Criminal Justice, 20(2), 171-174.

- Palmiotto, M.J., \& Kingshott, B. F. (2010). "Community Policing and Spatial Analysis" in Spatial Policing (Editor Charles E. Crawford), Durham, N. Carolina: Carolina Academic Press, 43-57.

- Podlas, K. (2006). The "CSI Effect," exposing the media myth. Fordham Intellectual Property Media \& Entertainment Law Journal, 16, 429-465.

- Shelton, D. E., Kim, Y. S., \& Barak, G. (2006). A study of juror expectations and demands concerning scientific evidence: Does the "CSI Effect" exist? Vanderbilt Journal of Entertainment \& Technology Law, 9, 331-338.

- Smith, S. M., Stinson, V., \& Patry, M. W. (2011). Fact of fiction? The myth and reality of the CSI Effect. Court Review, 47, 4-7.

- Stevens, D. (2011). Media and criminal justice. Sudbury, Mass.: Jones and Bartlett Pub.
- SPJ Code of Ethics - Society of Professional Journalists. (2019). Retrieved from https://www.spj.org/ethicscode.asp

- Thomas Guide 2006 Phoenix Arizona Including Maricopa County Street Guide Phoenix Metro Street Guide.

- The CSI Effect- Crime Museum. (2019). Retrieved from https://www.crimemuseum.org/crimelibrary/forensic-investigation/the-CSIeffect/

- The Public and Broadcasting. (2019). Retrieved from https://www.fcc.gov/media/radio/publi c-and-broadcasting.

- Xiang, Y., \& Sarvary, M. (2007). News consumption and media bias. Marketing Science, 26(5), 611-628.

- 10 Years of 26/11: Unforgettable Images of Mumbai Terror Attack. (2019). Retrieved from https://www.news18.com/photogallery/ india/10-years-after-2611-unforgettableimages-of-mumbai-terror-attack1950643.html 